Journal of Community Based Environmental Engineering and Management, 2021, Vol. 5, No. 2: 83-90

\title{
COMMUNITY-BASED ORGANIC WASTE PROCESSING USING BSF MAGGOT BIOCONVERSION
}

\author{
Mohamad Satori ${ }^{1}$, Ivan Chofyan ${ }^{2}$, Yuliadi $^{3}$, Otong Rukmana ${ }^{4}$, Ira Ayu Wulandari ${ }^{5}$, Fathiya Izzatunnisaa ${ }^{6}$, \\ Rifky Pajar Kemaludin ${ }^{7}$, Aji Saeful Rohman ${ }^{8}$ \\ ${ }^{1,4,5,6,7,8)}$ Department of Industry, Faculty of Industry, Bandung Islamic University \\ 2) Department of Urban and Regional Planning, Faculty of Industry, Bandung Islamic University \\ ${ }^{3)}$ Department of Mining, Faculty of Industry, Bandung Islamic University
}

\begin{abstract}
Organic waste is the largest composition of waste generated by the people of Indonesia, which is around $50-60 \%$. This type of waste, especially food waste, is easy to smell if it is stored for too long so that it has the potential to pollute the environment. On the other hand, organic waste has good nutrients that can be generated, including through BSF (Black Soldier Fly) maggot bioconversion treatment. The BSF maggot bioconversion method is a method of processing organic waste which is carried out by converting organic matter into other products that are useful and have added value by utilizing biological processes from microorganisms and enzymes. Organic waste treatment with this method is generally carried out on a community-based basis and is integrated with the development of agriculture, fisheries and animal husbandry, because maggot cultivation produces commodities of economic value such as compost and maggot larvae. Compost contains very good nutrients so that it can be used for organic farming and maggot contains high protein that can be used for animal feed and fisheries. The implementation of this program was piloted in the boarding school community, namely the Az-Zakaria Islamic Boarding School which is managed by the Az-Zakaria Islamic Education Foundation (YPI) in Sindangbarang Village, Jalaksana District, Kuningan Regency. The result of this implementation is the formation of a new group of entrepreneurs engaged in the cultivation and utilization of BSF maggots.
\end{abstract}

Keywords: Bioconversion, BSF Maggot, Organic waste

\section{Introduction}

Sindangbarang village is one of the villages located in Jalaksana District, Kuningan Regency, West Java Province which has a population of about 4040 people, most of whom have farmers' livelihoods. In the conditions of the Covid-19 pandemic all is restricted, so that economic activity becomes hampered, so

\footnotetext{
${ }^{*}$ E-mail: m.satori@unisba.ac.id
}

Received: 30 August 2021

Revised: 16 September 2021

Accepted: 16 September 2021

DOI: $10.23969 /$ jcbeem.v5i2.4445 farmers cannot sell their agricultural products. The decline of the economy has an impact on the food crisis, especially for the lower society.

This is in agreement with the statement of the Governor of West Java, Ridwan Kamil, who stated that West Java's prediction in 2021 will experience a food crisis caused by the closure of imports from exporting countries related to the COVID-19 pandemic (Radar Bogor, December $4,2020)$. In addition to having an effect on the economy, the COVID-19 pandemic also has an impact on the world of education that still has to run by following the provisions of New Habit Adaptation (AKB). 
The main problem faced by the community today is the lack of knowledge of organic waste management properly, in addition to the economic resilience of students, especially in the current pandemic, many students parents are affected by the Covid-19 pandemic. Therefore, students is required to live independently by relying on the resources around boarding school. In fact, there are currently efforts that can be done with very limited methods and scales, ranging from agriculture to fisheries. However, this potential has not been managed to the fullest. This Community Service activity is carried out to play a role in solving the problems faced by community by providing solutions on ways and/or technology both to process organic waste and utilize the potential of waste so that it becomes a new entrepreneur by turning organic waste into other useful products and adding value to them.

The paradigm of society often considers waste as waste material produced from human activities discarded because it is no longer used or considered no longer useful (Tchobanoglous, 2002 in Satori, 2018). By viewing waste only as waste, then without good management waste can pollute the environment, disrupt environmental health, reduce comfort and aesthetics. In the new paradigm, waste is not only seen as wasted material, but also as a resource. Among the waste materials there is the potential for resources that can be recovered (Satori, 2014). Organic waste can be converted into compost in a variety of composting methods. One of the techniques of composting organic waste is with the bioconversion of maggot BSF (Black Soldier Fly). Bioconversion is an ongoing process that utilizes insect larvae to transform organic waste. Furthermore, the larvae of such insects convert nutrients from waste and store them as biomass (Leong et al, 2016). Organic waste is converted by the process of biotransformation into organic matter consisting of polypeptid containing proteins, lipids, peptides, amino acids, chitin, and vitamins (Liu, C., Wang, C., Yao, H, 2019). Therefore, BSF maggot flies are considered nonpest and beneficial insects. Insects are considered an important source of protein for the 21 st century (Rui, M. et al, 2017).

The use of Maggot BSF Bioconversion is very profitable and promising as an organic waste processor. BSF larvae can be used as a source of protein for animal feed such as catfish and chickens. BSF larvae themselves contain 40$50 \%$ protein including essential amino acids that can be used as a substitute for fish meal and soy pulp in animal feed mixtures (Wardhana, 2016). Another advantage obtained from Bioconversion Maggot BSF is a liquid organic fertilizer that has a high amino acid content and compost. Therefore, BSF Larva bioconversion is an attractive waste recycling technology that generates added value, especially for low-and middle-income countries. In addition to producing waste reduction, products in the form of prepupa, animal feed, this also opens up new economic opportunities for small entrepreneurs in developing countries (Nguyen et al, 2015).

\section{Research Methodology}

The implementation of bioconversion to the community will be carried out using learning by doing methods, where bioconversion communication is carried out while carrying out the work. Based on the analysis of potential, the main problems faced, and external targets, the solution is to provide training on organic waste processing by using boarding school-based BSF maggot bioconversion and entrepreneurial debriefing for students, as well as providing assistance for organic waste management practices with BSF maggots and creating new boarding school-based entrepreneurial groups. The stage of community service activities can be described as follows:

1. Stage 1, initial or preliminary survey to partner premises aimed at ensuring the availability of venues for the application of 
Maggot BSF bioconversion. In addition, there is also a calculation of organic waste so that bioconversion can be optimally useful.

2. Stage 2, the preparation stage of tools and materials. The preparation of all components of this tool is carried out directly in the partner's place.

3. Stage 3, training and mentoring to participants on organic waste processing procedures with Maggot BSF bioconversion by the team, which began with a pretest using questionnaires to find out the participants' initial knowledge.

4. Stage 4, monitoring evaluation, namely by looking at the results of training and mentoring both in the implementation and knowledge of participants through the dissemination of the 2 nd questionnaire.

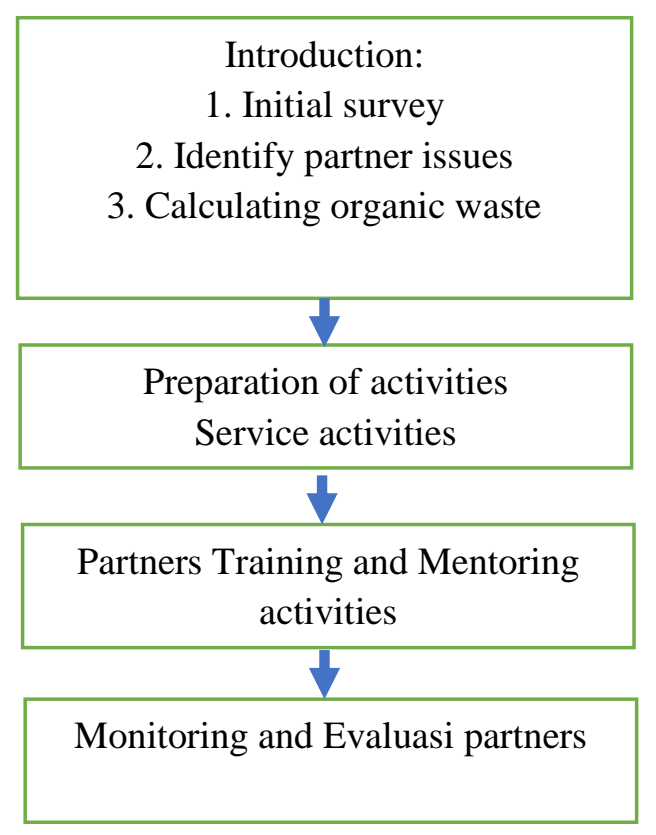

Figure 1. The stage of community service activities

\section{Result and Discussion}

Base Line Survey

The survey was conducted by spreading questionnaires to all participants. Questionnaires are divided into 3 groups, namely: (a) knowledge, (b) attitude, and (c) behavior (practice). The purpose of the survey is to find out how their knowledge, attitudes and actions are related to the processing of organic waste. The results of the survey both before and after the assistance are summarized in Tables 1, 2, and 3 .

Important note from the results of the participants' survey who participated in the training is that in knowledge the participants are generally quite good, for example about the types of waste, including garbage that includes organic, processing organic waste into compost and others. However, sufficient knowledge cannot guarantee that daily attitudes and behaviors are in accordance with his knowledge. The attitude of those who agree to process organic waste is about $28 \%$, and behavior in waste processing is still less about $4 \%$ which is always consistent, $28 \%$ often do and $48 \%$ sometimes do organic waste processing when there are already facilities. The public knows how to sort but it is not yet certain to do the sorting. Likewise, people know the processing of organic waste into compost but not necessarily they do composting, and others. 
Table 1. Knowledge

\begin{tabular}{|c|c|c|c|c|c|}
\hline \multirow{3}{*}{ Numb. } & \multirow{3}{*}{ Statement } & \multicolumn{4}{|c|}{ Result } \\
\hline & & \multicolumn{2}{|c|}{ Before } & \multicolumn{2}{|c|}{ After } \\
\hline & & $\begin{array}{l}\text { Don't } \\
\text { Know }\end{array}$ & Know & $\begin{array}{l}\text { Don't } \\
\text { Know }\end{array}$ & Know \\
\hline 1 & About waste management with 3R pattern & $24 \%$ & $76 \%$ & $100 \%$ & $0 \%$ \\
\hline 2 & How to sort the trash & $72 \%$ & $28 \%$ & $100 \%$ & $0 \%$ \\
\hline 3 & $\begin{array}{l}\text { How to make compost by utilizing organic waste } \\
\text { (kitchen waste, leaves, leftovers)? }\end{array}$ & $72 \%$ & $28 \%$ & $100 \%$ & $0 \%$ \\
\hline 4 & $\begin{array}{l}\text { Az-Zakaria Boarding school will create an organic } \\
\text { garden }\end{array}$ & $40 \%$ & $60 \%$ & $100 \%$ & $0 \%$ \\
\hline 5 & $\begin{array}{l}\text { In the Boarding school area will be made "waste } \\
\text { processing with Maggot BSF" as a means of processing } \\
\text { organic waste into compost. }\end{array}$ & $68 \%$ & $32 \%$ & $100 \%$ & $0 \%$ \\
\hline 6 & $\begin{array}{l}\text { Garbage that comes from the kitchen or yard such as } \\
\text { leaves is organic waste. }\end{array}$ & $68 \%$ & $32 \%$ & $100 \%$ & $0 \%$ \\
\hline 7 & $\begin{array}{l}\text { Organic waste such as food waste and leaves can be } \\
\text { processed into compost? }\end{array}$ & $64 \%$ & $36 \%$ & $100 \%$ & $0 \%$ \\
\hline 8 & $\begin{array}{l}\text { Garbage such as neon/used lights, used battery stones, } \\
\text { pampers, pads is hazardous and toxic garbage? }\end{array}$ & $76 \%$ & $24 \%$ & $100 \%$ & $0 \%$ \\
\hline 9 & $\begin{array}{l}\text { Inorganic types of waste such as metals, plastics, paper } \\
\text { can be recycled into certain products? }\end{array}$ & $72 \%$ & $28 \%$ & $100 \%$ & $0 \%$ \\
\hline 10 & $\begin{array}{l}\text { Packaging waste such as coffee wraps, plastic bags, etc. } \\
\text { can be processed into craft products? }\end{array}$ & $72 \%$ & $28 \%$ & $100 \%$ & $0 \%$ \\
\hline 11 & Burning garbage is prohibited under Law No. 18 of 2008. & $84 \%$ & $16 \%$ & $92 \%$ & $8 \%$ \\
\hline
\end{tabular}

Table 2. Attitude

\begin{tabular}{|c|c|c|c|c|c|c|}
\hline \multirow[b]{2}{*}{ Numb. } & \multirow[b]{2}{*}{ Statement } & \multicolumn{5}{|c|}{ Result } \\
\hline & & & $\begin{array}{c}\text { Strongly } \\
\text { Agree }\end{array}$ & Agree & Disagree & $\begin{array}{l}\text { Strongly } \\
\text { Disagree }\end{array}$ \\
\hline \multirow[t]{2}{*}{1} & $\begin{array}{l}\text { I prefer if waste management in the } \\
\text { home environment is done by local } \\
\text { residents/neighborhood/officers }\end{array}$ & Before & $24 \%$ & $60 \%$ & $16 \%$ & $0 \%$ \\
\hline & $\begin{array}{l}\text { alternately/together to the temporary } \\
\text { shelter rather than done by janitors. }\end{array}$ & After & $56 \%$ & $40 \%$ & $8 \%$ & $0 \%$ \\
\hline
\end{tabular}




\section{Result}

\begin{tabular}{|c|c|c|c|c|c|c|}
\hline Numb. & Statement & & $\begin{array}{c}\text { Strongly } \\
\text { Agree }\end{array}$ & Agree & Disagree & $\begin{array}{l}\text { Strongly } \\
\text { Disagree }\end{array}$ \\
\hline \multirow{2}{*}{2} & \multirow{2}{*}{$\begin{array}{l}\text { I would rather have waste management } \\
\text { done by being transported and dumped } \\
\text { into landfill all by janitors rather than } \\
\text { partially processed either alone or } \\
\text { collectively on neighborhood. }\end{array}$} & Before & $20 \%$ & $16 \%$ & $36 \%$ & $28 \%$ \\
\hline & & After & $32 \%$ & $20 \%$ & $20 \%$ & $8 \%$ \\
\hline \multirow{2}{*}{3} & \multirow{2}{*}{$\begin{array}{l}\text { I would rather put mixed garbage in one } \\
\text { container than be sorted mainly between } \\
\text { wet (organic) and dry (inorganic) waste. }\end{array}$} & Before & $8 \%$ & $36 \%$ & $16 \%$ & $40 \%$ \\
\hline & & After & $28 \%$ & $40 \%$ & $20 \%$ & $12 \%$ \\
\hline \multirow{2}{*}{4} & \multirow{2}{*}{$\begin{array}{l}\text { I would rather put organic waste in the } \\
\text { nearest biopore/composter/other com- } \\
\text { poster than throw it in the front trash of } \\
\text { the house. }\end{array}$} & Before & $16 \%$ & $28 \%$ & $56 \%$ & $0 \%$ \\
\hline & & After & $44 \%$ & $48 \%$ & $24 \%$ & $0 \%$ \\
\hline \multirow{2}{*}{5} & \multirow{2}{*}{$\begin{array}{l}\text { If I have a yard with lots of trees, then I } \\
\text { would rather bury a fallen leaf than burn } \\
\text { it in the yard/put it together with other } \\
\text { garbage. }\end{array}$} & Before & $28 \%$ & $64 \%$ & $8 \%$ & $0 \%$ \\
\hline & & After & $56 \%$ & $44 \%$ & $4 \%$ & $0 \%$ \\
\hline \multirow{2}{*}{6} & \multirow{2}{*}{$\begin{array}{l}\text { I would rather keep leftover waste in a } \\
\text { separate place than put it together with } \\
\text { other garbage because it gets the other } \\
\text { trash wet. }\end{array}$} & Before & $28 \%$ & $64 \%$ & $8 \%$ & $0 \%$ \\
\hline & & After & $56 \%$ & $48 \%$ & $0 \%$ & $0 \%$ \\
\hline
\end{tabular}

Table 3. Behavior (Practice)

\begin{tabular}{|c|c|c|c|c|c|c|}
\hline \multirow{2}{*}{ Numb. } & \multirow{2}{*}{ Statement } & \multicolumn{5}{|c|}{ Result } \\
\hline & & & Always & Often & Sometimes & Never \\
\hline \multirow{2}{*}{1} & \multirow{2}{*}{$\begin{array}{l}\text { I store waste in a separate manner } \\
\text { (organic, inorganic and hazardous and } \\
\text { toxic substance) at home so that waste } \\
\text { facilitates in the recycling process both } \\
\text { by myself and done on neighborhood } \\
\text { and regional scales. }\end{array}$} & Before & $27 \%$ & $0 \%$ & $42 \%$ & $31 \%$ \\
\hline & & After & $32 \%$ & $40 \%$ & $20 \%$ & $8 \%$ \\
\hline \multirow{2}{*}{2} & \multirow{2}{*}{$\begin{array}{l}\text { I swept and collected trash from the } \\
\text { street in front of my house }\end{array}$} & Before & $42 \%$ & $0 \%$ & $58 \%$ & $0 \%$ \\
\hline & & After & $40 \%$ & $32 \%$ & $28 \%$ & $0 \%$ \\
\hline \multirow{2}{*}{3} & \multirow{2}{*}{$\begin{array}{l}\text { Me/my family pays the garbage } \\
\text { dues/levy through neighborhood every } \\
\text { month. }\end{array}$} & Before & $28 \%$ & $0 \%$ & $52 \%$ & $20 \%$ \\
\hline & & After & $40 \%$ & $36 \%$ & $16 \%$ & $8 \%$ \\
\hline
\end{tabular}




\begin{tabular}{|c|c|c|c|c|c|c|}
\hline \multirow{2}{*}{ Numb. } & \multirow{2}{*}{ Statement } & \multicolumn{5}{|c|}{ Result } \\
\hline & & & Always & Often & Sometimes & Never \\
\hline \multirow{2}{*}{4} & \multirow{2}{*}{$\begin{array}{l}\text { Garbage that comes from the kitchen } \\
\text { and garden is processed by itself either } \\
\text { using biopore, compost or put into a } \\
\text { brick composter. }\end{array}$} & Before & $4 \%$ & $4 \%$ & $11 \%$ & $81 \%$ \\
\hline & & After & $4 \%$ & $28 \%$ & $48 \%$ & $24 \%$ \\
\hline \multirow{2}{*}{5} & \multirow{2}{*}{$\begin{array}{l}\text { I store plastic waste / cans / cardboard } \\
\text { that is still good to be reused or to be } \\
\text { sold to junkyards }\end{array}$} & Before & $56 \%$ & $12 \%$ & $4 \%$ & $28 \%$ \\
\hline & & After & $60 \%$ & $12 \%$ & $12 \%$ & $16 \%$ \\
\hline \multirow{2}{*}{6} & \multirow{2}{*}{$\begin{array}{l}\text { My family/my family reuses used } \\
\text { newspaper/magazines for wrapping or } \\
\text { for other purposes }\end{array}$} & Before & $42 \%$ & $0 \%$ & $58 \%$ & $0 \%$ \\
\hline & & After & $48 \%$ & $20 \%$ & $28 \%$ & $0 \%$ \\
\hline
\end{tabular}

\section{Training}

The training provided to partners (students and the community around boarding school) is organic waste processing training with BSF maggot bioconversion techniques (BSF maggot house construction), entrepreneurial debriefing, and utilization of compost and maggots for agriculture and fisheries. This training is followed by students and the surrounding community with learning by doing methods.

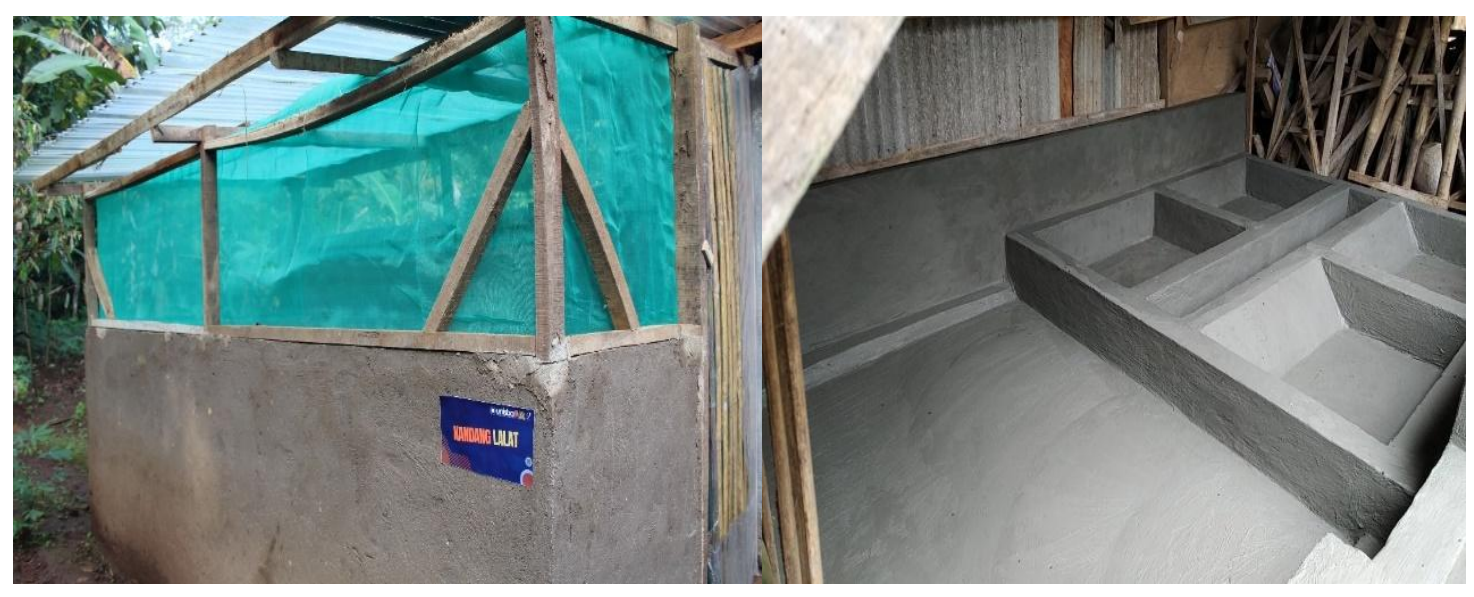

Figure 2. Building Maggot BSF House 


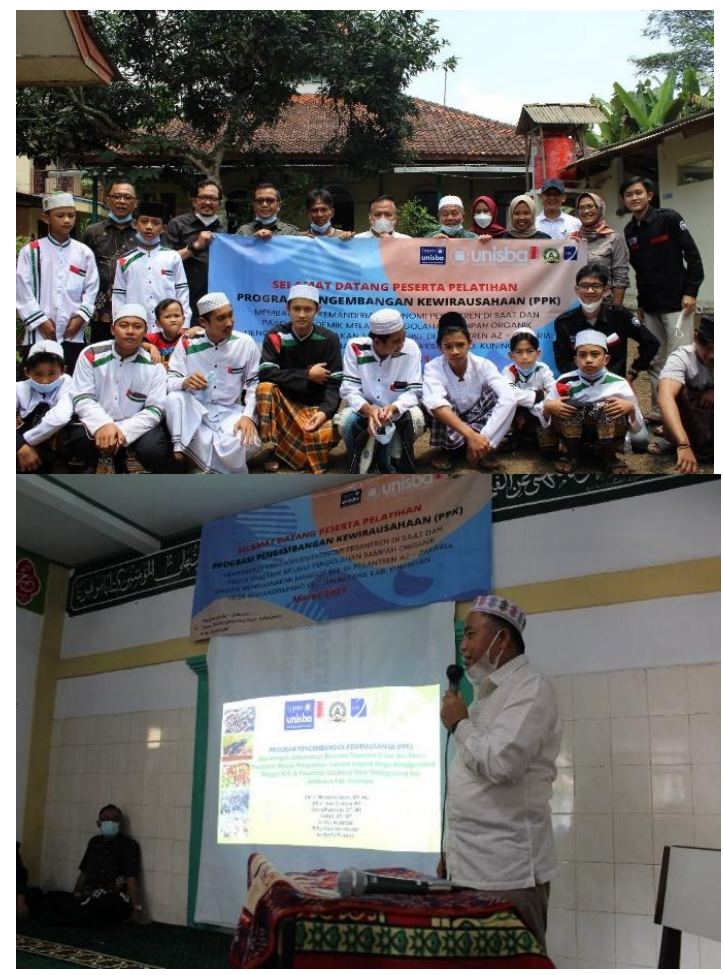

Figure 3. Providing material by service team

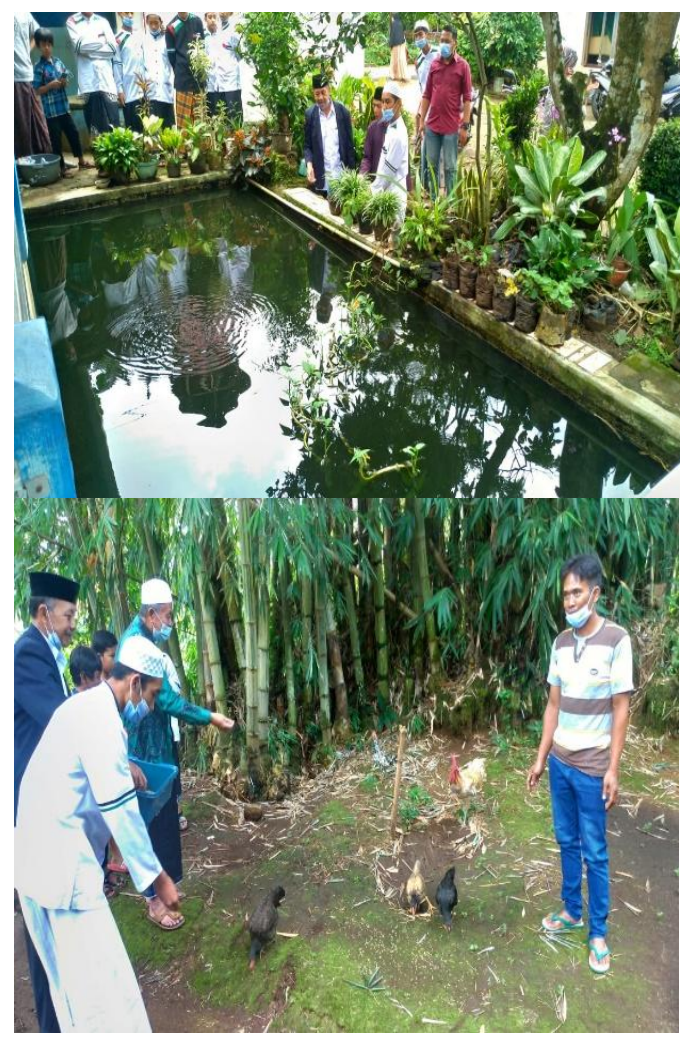

Figure 4. Practice of utilizing Maggot BSF for livestock and fisheries

\section{Implementation of Mentoring}

Evaluation the results of mentoring is carried out by spreading questionnaires back to participants who participate in training and mentoring, and reviewing the situation in boarding schools to see if there are changes or not after community service activities. Based on the results of the evaluation through the dissemination of questionnaires shown in Tables 1, 2 and 3, there was a change in aspects of knowledge, attitudes and behavior. Some aspects that stand out are the following aspects:

1. Participants' knowledge of waste management with 3R pattern increased considerably from $24 \%$ to $100 \%$

2. Participants' knowledge of waste coming from the kitchen or yard such as leaves is organic waste increased from $68 \%$ to $100 \%$

\section{Establishment of an Entrepreneurial Group}

One of the targets that want to be achieved from this community service activity is the formation of a new entrepreneurial group. This is done to maximize the bioconversion of organic waste with BSF maggots so that it can be a source of income for students and the community around the boarding school. The formation was carried out in deliberation so that the team was formed at the Az-Zakaria boarding school. The team consists of several fields, including maggot cultivation, livestock farming, fisheries, organic farming, and marketing. To further strengthen the existence of this team is being submitted to the Village, in order to get a statement letter and approved by the Village Head of Sindangbarang.

\section{Conclusion}

From the community service activities that we have completed, then we can conclude that the garbage that has been an environmental problem in the Az-Zakaria boarding school of Sindangbarang Village, Jalaksana Kuningan, can be converted into products that can be utilized and are economically valuable through Maggot 
BSF bioconversion technology. The economic potential that can be developed and become a new entrepreneur based on boarding schools is catfish cultivation, chicken farming and the sale of maggot larvae (fresh maggots) and kasgots that can be utilized for plantations or sold to the community. The economic potential that can be developed through the cultivation of BSF maggots can be an alternative business in the pandemic period. In general, participants' knowledge about organic waste processing, especially kitchen waste before maggot bioconversion training is quite good. While attitudes and behaviors about the management of new kitchen waste increased after participants conducted training and mentoring. This is realized when monitoring is carried out, $75 \%$ of organic waste in the environment around boarding schools can be resolved.

\section{Recommendation}

During training and mentoring, of course, we get various important information, especially related to the sustainability of the program. For this reason, we propose the following suggestions:

1. Local governments, especially the village government, should be able to facilitate the growth of maggot cultivation in the community.

2. The government should be able to help market access and capital.

3. The community should be required to sort waste into at least 3 groups, namely organic waste, inorganic waste and hazardous and toxic substance waste.

4. The government should socialize continuously and continuously, especially related to the sorting of waste and processing organic waste into compost.

\section{References}

Leong, S.Y., Kutty, S.R.M., Malakahmad, A., Tan, C.K. (2016). Feasibility Study of
Biodiesel Production Using Lipids of Hermetia illucens Larva Fed With Organic Waste. Waste Manage. 47: 8490.

Liu, C., Wang, C., Yao, H. (2019). Comprehensive Resource Utilization of Waste Using the Black Soldier Fly (Hermetia illucens (L.)). Diptera: Stratiomyidae. Animals 2019, 9, 349.

Nguyen, T.T.X., Tomberlin, J.K., Vanlaerhoven, S., (2015). Ability Of Black Soldier Fly (Diptera: Stratiomyidae) Larvae To Recycle Food Waste. Environ Entomol. 44(2):406-410. doi:10.1093/ee/nvv002.

Radar Bogor. (2020). Tahun Depan Jawa Barat Diprediksi Alami Krisis Pangan. www.radarbogor.id/2020/12/04/tahundepan-jawa-barat-diprediksi-alami-krisis pangan/ (diakses 24 Mei 2021).

Rui, M., Sánchez-López, A., Leal, R.S., Martínez-Llorens, S., Oliva-Teles, A., Peres, H. (2017). Black Soldier Fly (Hermetia illucens) Pre-Pupae Meal As A Fish Meal Replacement In Diets For European Seabass (Dicentrarchus labrax). Aquaculture 2017, 476, 79-85.

Satori, M. 2014. Kajian Potensi Ekonomi Berbasis Sampah untuk Menumbuhkembangkan Ecopreneur dalam Mendukung Tamansari Ecovillage. BPLH Kota Bandung.

Satori, M et.al (2018). Pengolahan Sampah Organik Rumah Tangga Dengan Metode Bata Terawang. Ethos (Jurnal Penelitian dan Pengabdian Masyarakat): 135-145

Wardhana, A.H. (2016). Black Soldier Fly (Hermetia illucens) as an Alternative Protein Source for Animal Feed. WART 